\title{
Study of various configurations of hybrid PV/T system
}

\author{
H. Ben Cheikh El Hocine, M. Marir-Benabbas \\ Laboratory Modeling Renewable Energy Devices and Nanometric, Department of ELECTRONIC, \\ University CONSTANTINE 1, ALGERIA \\ Email: hanene012009@hotmail.fr \\ Received: October 5, 2019. Revised: September 26, 2021. Accepted: October 25, 2021. Published: November 14, 2021.
}

\begin{abstract}
- in this study, an attempt has been made to evaluate the theoretical performance and evaluation of a hybrid $\mathrm{PV} /$ thermal (PV/T) collector based on dual heat extraction operation a function of climatic and design parameters. On the first hand, the different configurations of hybrid collectors are considered for the present study which are defined as unglazed PV/T air heaters, with and without tedlar, PVT hybrid water collector, in the second hand two configurations with dual extraction operation (water and air as heat removal fluid) are presented which are defined as dual PV/T model with tedlar, dual hybrid PV/T without tedlar. Analytical expressions for the temperatures of solar cells, back surface of the module, outlet air, and outlet water of those configurations have been derived. Numerical computations have been carried out for composite climate and the results for different configurations have been compared. Our results clearly show the direct impact of various parameters, in particular the solar radiation, ambient temperature, mass flow rate on the variation of outlet and solar cell of the collector.
\end{abstract}

Keywords- Hybrid solar system; solar photovoltaic thermal (PV/T) collector; thermal performance; Performance analysis; simulation.

\section{INTRODUCTION}

Recent hike in oil prices has resulted in strong stimulation of research into renewable energy because such research can make major contributions to the diversity and security of energy supply, to the economic development and to the clean local environment.

Renewable energy technologies currently supply $13.3 \%$ of the world's primary energy needs [1] and their future potential depends on exploiting the resources that are available locally and on overcoming the environmental challenges as well as winning public acceptance. Various forms of renewable energy depend primarily on incoming solar radiation, which totals about 3.8 million EJ per year.

To improve the electrical performance of photovoltaic PV generator, it was brought to recover the heat dissipated by convection and conduction and when operating in a state of 'hot spots' and / or normal state [2], this led us to consider the use of a conventional hybrid collector in order to operate an electrical and thermal performance for both occupied the same space.
A photovoltaic/thermal hybrid solar system (or PVT system for simplicity) is a combination of photovoltaic (PV) and solar thermal components/systems which produce both electricity and heat from one integrated component or system. The basic device of a PV system is the PV cell. Cells may be grouped to form panels or arrays.

In the solar thermal system, external electrical energy is required to circulate the working fluid through the system. On the other hand, in the PV system, the electrical efficiency of the system decreases rapidly as the PV module temperature increases. Therefore, in order to achieve higher electrical efficiency, the PV module should be cooled by removing the heat in some way. In order to eliminate an external electrical source and to cool the PV module, the PV module should be combined with the solar air/water heater collector. This type of system is called solar photovoltaic thermal (PV/T) collector. The PV/T collector produces thermal and electrical energy simultaneously.

A number of theoretical as well as experimental studies have been made on (PV/T) systems with air and liquid as working fluid. Kern and Russell [3] are the first who give main concept of $\mathrm{PV} / \mathrm{T}$ collector using water or air as the heat removal fluid. Hendrie and Raghuraman [4] have made a comparative experimental study on photovoltaic thermal collectors with liquid and air as working fluid.

Tiwari and al. [5] have evaluated an overall thermal efficiency of four configurations of $\mathrm{PV} / \mathrm{T}$ solar air heating systems. The methodology adopted for analyzing the unglazed hybrid PV/T solar air collector by Tiwari et al. [6] has been considered.

Nayak and al. [7] have studied the effect of evaporative and conductive losses from the plant and floor respectively has been considered to predict the performance of a $p$ articular greenhouse in terms of various design and climatic parameters. It have observed that the plant room air temperatures are higher in the case of photovoltaic thermal (PV/T) without airflow due to direct transfer of thermal energy into the greenhouse. However, the overall thermal efficiency of a hybrid photovoltaic thermal (PV/T) air collector is higher due to low operating temperature.

Anand and al. [8] have studied the exergy efficiency of unglazed PV/T air heating module for the cold and cloudy 
condition of Srinagar. In his analysis an increase of about $2-$ $3 \%$ exergy due to thermal energy in addition to its $12 \%$ electrical outputs from $\mathrm{PV} / \mathrm{T}$ system, this makes an overall electrical efficiency of about $14-15 \%$ of PV/T system.

Dubey and al. [9] have gives the detailed analysis of overall annual energy and exergy gain from hybrid PV/T solar water heating system. This system will increase the total carbon emission reduction and overall carbon credit earned as per the norms of Kyoto Protocol if it is integrated in a building. They have derived the expression for temperature dependent electrical efficiency considering glass to glass and glass to tedlar type PV modules [10].

Dubey and al. [11] have derived the analytical expressions for $\mathrm{N}$ hybrid photovoltaic/thermal (PV/T) air collectors connected in series. The performance of collectors is evaluated by considering the two different cases. Shows the detailed analysis of energy, exergy and electrical energy by varying the number of collectors and air velocity considering four weather conditions and five different cities. It is found that the collectors fully covered by PV module and air flows below the absorber plate gives better results in terms of thermal energy, electrical energy and exergy gain. Physical implementation of BIPV system has also been evaluated.

Chow [12] has done a review on $\mathrm{PV} / \mathrm{T}$ hybrid solar technology especially PV/T air collector systems. His article gives a review of the trend of development of the technology, in particular the advancements in recent years and the future work required.

Sarhaddi and al. [13] have studied the performance evaluation of a PV/T air collector was carried out. A detailed thermal and electrical model was developed to calculate the thermal and electrical parameters of at ypical PV/T air collector. Some corrections were done on heat loss coefficients in order to improve the thermal model of a PV/T air collector and a better electrical model was used to increase the calculations precision of $\mathrm{PV} / \mathrm{T}$ air collector electrical parameters.

Adnan and al. [14] have presented the state-of-the-art on flat plate $\mathrm{PV} / \mathrm{T}$ collector classification, design and performance evaluation of water, air and combination of water and/or air based. This review also covers the future development of flat plate $\mathrm{PV} / \mathrm{T}$ solar collector on building integrated photovoltaic (BIPV) and building integrated photovoltaic/thermal (BIPVT) applications. Different designs feature and performance of flat plate PV/T solar collectors have been compared and discussed.

Recently, Zondag [15] has carried out rigorous review on PV-thermal collector systems, carried out by various scientists till 2006. His review included the history and importance of photovoltaic hybrid system and its application in various sectors. It also includes characteristics equations, study of design parameters, and marketing, etc.

Teo and al. [16] have presented the comparison of the electrical efficiency of the PV module with and without cooling. By varying the air flow rate through the duct, the electrical performance will also be investigated. In addition, a simulation model is developed to examine the actual temperature profile of Photovoltaic cell during operation. Without active cooling, the temperature of the module was high and solar cells can only achieve an efficiency of $8-9 \%$. However, when the module was operated under active cooling condition, the temperature dropped significantly leading to an increase in efficiency of solar cells to between $12 \%$ and $14 \%$.

In this paper, an attempt has been made to evaluate the performance of following configuration of hybrid $\mathrm{PV} / \mathrm{T}$ systems:

- Unglazed hybrid PV/T air collector with tedlar, (Model I), Fig. 1(i),

- Unglazed hybrid PV/T air collector without tedlar, (Model II), Fig. 1(ii),

- $\quad$ PVT hybrid water collector, Fig. 2.

- Dual PV/T model with tedlar, (Model III), Fig. 3(i $\left.i_{1}\right)$, Dual hybrid PV/T without tedlar, (Model IV), Fig. 3( $\left.\mathrm{i}_{2}\right)$

\section{THERMAL ANALYSIS OF PV/T AIR COLLECTOR}

Fig. 1 shows the cross-sectional view of a $\mathrm{P} V / \mathrm{T}$ air collector for two configurations. its equivalent thermal resistant circuit and the energy balance equation for each component of a $\mathrm{P} V / \mathrm{T}$ air collector gives the thermal parameters and thermal efficiency of a $\mathrm{PV} / \mathrm{T}$ air collector are developed by $[5,13]$
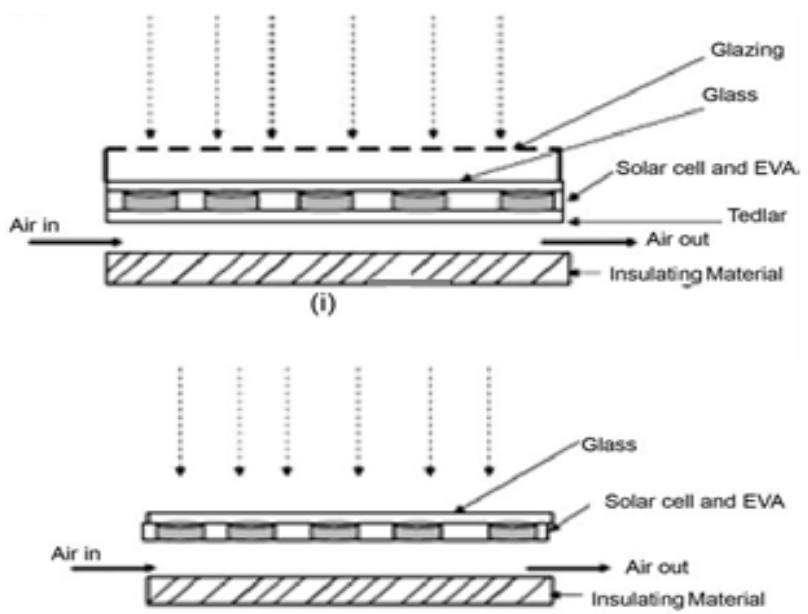

(ii)

Figure 1. (i) The cross-sectional view of a PV/T air collector with tedlar (Model I), (ii) without tedlar (Model II).

\section{A. For the case of PV/T with Tedlar}

The energy balance for a P V panel under a s teady state condition can be given as:

$$
(\tau \alpha)_{\text {eff }}=U_{t}\left(T_{\text {cell }}-T_{a}\right)+U_{\tau}\left(T_{\text {cell }}-T_{\text {abs }}\right)
$$

The energy balance for absorber can be written as:

$$
U_{T}\left(T_{\text {cell }}-T_{\text {abs }}\right)=h_{f \text { air }}\left(T_{\text {abs }}-T_{f}\right)
$$

The outlet temperature is calculated by

$$
\begin{aligned}
T_{\text {fout }}= & \left(T_{a}+\frac{S}{U_{L}}\right)\left(1-\exp \left(\frac{-U_{L} b L}{\dot{m} C_{\text {air }}}\right)\right) \\
& +T_{\text {fin }} \exp \left(\frac{-U_{L} w L}{\dot{m} C_{\text {air }}}\right)
\end{aligned}
$$

$(\tau \alpha)_{\text {eff }}$ is the effective transmittance, it was calculated by

$$
(\tau \alpha)_{e f f}=\tau_{g}\left[\alpha_{e} \beta_{e}+\alpha_{T}\left(1-\beta_{e}\right)-\beta_{c} \eta_{e l}\right]
$$


The value of the transmission-absorption factor is inserted into the corresponding thermal-yield model.

The useful collected heat of the air flow is given by the Equation:

$$
\begin{aligned}
Q_{u-\text { air }} & =\dot{m} C_{p}\left(T_{\text {fout }}-T_{\text {fin }}\right) \\
& =\frac{\dot{m} C_{\text {air }}}{U_{L}}\left[s-U_{L}\left(T_{\text {fin }}-T_{a}\right)\right]\left(1-\exp \left(\frac{-U_{L} w L}{\dot{m} C_{\text {air }}}\right)\right)
\end{aligned}
$$

Where and $C_{\text {air }}$, are respectively, the mass flow rate and specific heat capacity of the coolant, (wL) the collector aperture area, $\mathrm{T}_{\text {fin }}$ and $\mathrm{T}_{\text {fout }}$ the coolant temperatures at the inlet and outlet, $\mathrm{U}_{\mathrm{L}}$ is the overall heat loss coefficient, it may be computed by using the concept of thermal network and is given by [13].

With

$S=h_{p 1} h_{p 2}(\tau \alpha)_{e f f} G$

The cell efficiency represented as a function of the module temperature. [17]

$$
\eta_{e l}=\eta_{0}\left(1-0.0045\left(T_{\text {cell }}-T_{\text {ref }}\right)\right)
$$

Where the $\eta_{0}$ is the reference efficiency of the solar cell at $\mathrm{T}_{\text {ref }}=25^{\circ} \mathrm{C}$ which is in our study $12 \%$.

Replacing equations (2), (4) in equation (1), and substituting it in (7), the temperature of the photovoltaic panel may be written as :

$$
T_{e}=\left(X_{1}-X_{2} \eta_{\Theta}\right) G+X_{a} T_{a}+X_{4} T_{\text {fin }}
$$

Where

$$
\begin{aligned}
X_{1}= & \left(1+U_{T} h_{p 1} /\left(U_{t T}+h_{f}\right)\right) \frac{\tau_{g}\left(\alpha_{c} \beta_{c}+\alpha_{T}\left(1-\beta_{c}\right)\right)}{U_{t}+U_{T}} \\
& +X_{4} \frac{\eta_{t h-a i r}}{2 m C_{\text {air }}} \\
X_{2}= & \frac{\beta_{c} \tau_{g}\left(1+U_{T} h_{p 1} /\left(U_{t T}+h_{f, a i r}\right)\right)}{U_{t}+U_{T}} \\
X_{a=} & \frac{U_{t}+U_{t T} U_{T} /\left(U_{t T}+h_{f \text { air }}\right)}{U_{t}+U_{T}} \\
X_{4}= & \frac{U_{T} h_{f_{\text {air }}} /\left(U_{t T}+h_{f, a i r}\right)}{U_{t}+U_{T}}
\end{aligned}
$$

The expressions for $X_{1}, X_{2}, X_{3}$, and $X_{4}$ suggest that these should be constant. It can be noted that a linear relationship exists between the temperature of the PV panel $\left(\mathrm{T}_{\text {cell }}\right)$ and electrical efficiency $\left(\eta_{\mathrm{el}}\right)$. For constant value of solar radiation (G), the electrical efficiency of the system can be expressed as:

$$
\eta_{e l}=Y_{1}-Y_{2}\left(\frac{T_{f i n}-T_{a}}{G}\right)
$$

If $Y_{1}, Y_{2}$ are constant values, then the variation of electrical efficiency $\left(\eta_{\mathrm{el}}\right)$ of the system with $\mathrm{T}_{\mathrm{a}}$ and $\mathrm{T}_{\mathrm{fi}}$ should give a plane.

\section{B. For the case of PV/T without Tedlar:}

In the case of PV/T without Tedlar the energy balance for a PV panel under a steady state condition can be given as:

$$
(\tau \alpha)_{\text {eff }}=U_{t}\left(T_{\text {cell }}-T_{a}\right)+h_{\text {fair }}\left(T_{\text {cell }}-T_{f}\right)
$$

The effective transmittance in the case of $\mathrm{PV} / \mathrm{T}$ without Tedlar is defined as follows:

$$
(\tau \alpha)_{e f f}=\tau_{g} \beta_{e}\left(\alpha_{e}-\eta_{e l}\right)
$$

The useful collected heat of the air flow in this case is the same as that given by equation (5).

With

$S=h_{p}(\tau \alpha)_{e f f} G$

The value of $U_{L}$ in this case is given by [5].

The temperature of the photovoltaic panel in this case is similar as wrinting in equation (8).

with :

$X_{1}=\frac{\tau_{g} \alpha_{c} \beta_{c}+h_{f \text { air }} \eta_{t h} /\left(2 \dot{m} C_{\text {air }}\right)}{U_{t}+h_{f \text { air }}}$

$X_{2}=\frac{\tau_{g} \beta_{c}}{U_{t}+h_{f_{\text {air }}}}, \quad X_{\mathrm{a}}=\frac{U_{\mathrm{t}}}{U_{\mathrm{t}}+h_{f_{\text {air }}}}, \quad X_{4}=\frac{h_{f_{\text {air }}}}{U_{t}+h_{f_{\text {, air }}}}$

\section{PV/T hybrid water collector}

The concept of hybrid photovoltaic-thermal collector consists of superimposing both electrical and thermal energy functions. It is characterized by a combination sandwich between air and water. The lower face is isolated and does not absorber.

Figure 2 presents a description of a PV-T collector using water as coolant.

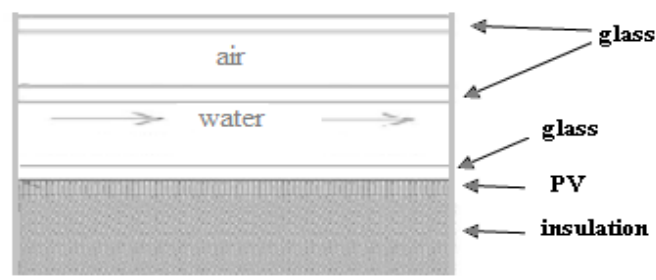

Fig. 2. Descriptive scheme for a solar photovoltaic thermal (PV/T) water collector

The set of equations constituting the balance of power is presented in the as follows, taking into account energy losses by conduction, convection, and radiation:

$$
\begin{aligned}
& (\tau \alpha)_{\text {eff }} G=U_{a}\left(T_{\text {cell }}-T_{g i}\right)++U_{b}\left(T_{\text {cell }}-T_{a}\right)+Q_{\text {watey }_{2} 2}(13 \\
& Q_{\text {u-watey }}=Q_{\text {water }, 1_{1}}+Q_{\text {water }_{2}} \\
& Q_{g-v i}=U_{2}\left(T_{g i}-T_{g e}\right)+U_{a}\left(T_{g i}-T_{\text {cell }}\right)+Q_{\text {water } 1} \\
& Q_{g-v e}=U_{2}\left(T_{g \theta}-T_{g i}\right)+U_{1}\left(T_{g g}-T_{a}\right)
\end{aligned}
$$


Using flow relations Released fluid / temperature [18], and the calculation of the flow of convective heat $\mathrm{Q}_{\text {water }}$, one exchanged between the internal glass at $\mathrm{T}_{\mathrm{gi}}$ working fluid at $\mathrm{T}_{\mathrm{f} \text {,water }}$ on the hand, and the flux $\mathrm{Q}_{\text {water }}$, exchanged between the module $\mathrm{PV}$ at $\mathrm{T}_{\text {cell }}$ and the working fluid (water) on the other hand, one can derive the temperature profile of the fluid in the collector.

$$
\begin{aligned}
T_{f \circ u t}= & \left(\frac{T_{g i}+T_{\text {cell }}}{2}\right)\left(1-\exp \left(\frac{-2 h_{f \text { water }} w L}{m C_{\text {water }}}\right)\right)+ \\
& +T_{f i n} \exp \left(\frac{-2 h_{f_{\text {w water }}} w L}{\dot{m} C_{\text {water }}}\right)
\end{aligned}
$$

The sum of these two fluxes gives the amount of useful energy recovered by the fluid in this case water.

$$
\begin{aligned}
& Q_{\text {u-watey }}=\dot{m} C_{\text {water }}\left(T_{\text {fout }}-T_{\text {fin }}\right) \\
& =\dot{m} C_{\text {water }}\left[\frac{T_{g i}+T_{\text {cell }}}{2}-T_{f i n}\right]_{\mathrm{X}} \\
& \quad\left(1-\exp \left(\frac{-2 h_{\text {fwater }} w L}{\dot{m} C_{\text {water }}}\right)\right)
\end{aligned}
$$

The efficiency is defined as the amount of useful energy produced divided by the amount of solar energy received by the collector.

$\eta_{t h}=\frac{Q_{u}}{w L G}$

Details of the calculation of transfer coefficients in the different layers will be repeating in the next section.

$$
\left(^{(\tau \alpha)_{e f f}}=\tau_{g} \alpha_{c}-\tau_{c e l l} \eta_{e \mathrm{l}}\right.
$$

Between the glass/panel PV and water [19], the convective heat transfer coefficient $h_{f \text {,water }}$ is calculated according to the flow regime and the Nusselt number, was chosen $\mathrm{Nu} 2=5.385$ [20].

\section{Hybrid PV/T system with dual extraction operation}

In this section we will combine the two collectors studied previously for a new hybrid PV/T with dual heat extraction operation

In the present paper we propose a new PV/T system design based on dual heat extraction operation, an attempt has been made to evaluate an overall thermal and electrical efficiency of two configurations; hybrid PV/T with and without tedlar.

Fig. 3 shows the cross-sectional view of a dual PV/T model for the two configurations. The thermal circuit diagram of each model has been show in fig. 4 .

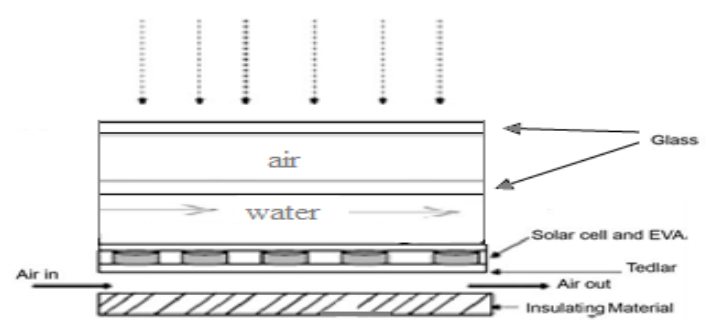

(i)

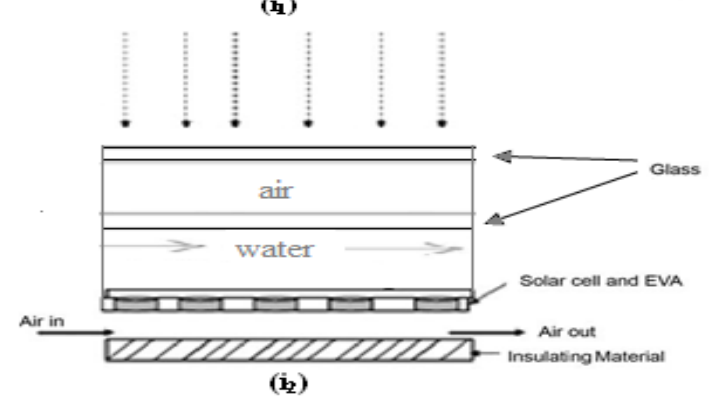

Figure. 3. $\left(i_{1}\right)$ The cross-sectional view for dual PV/T model with tedlar (Model III), ( $\mathrm{i}_{2}$ ) without tedlar (Model IV).

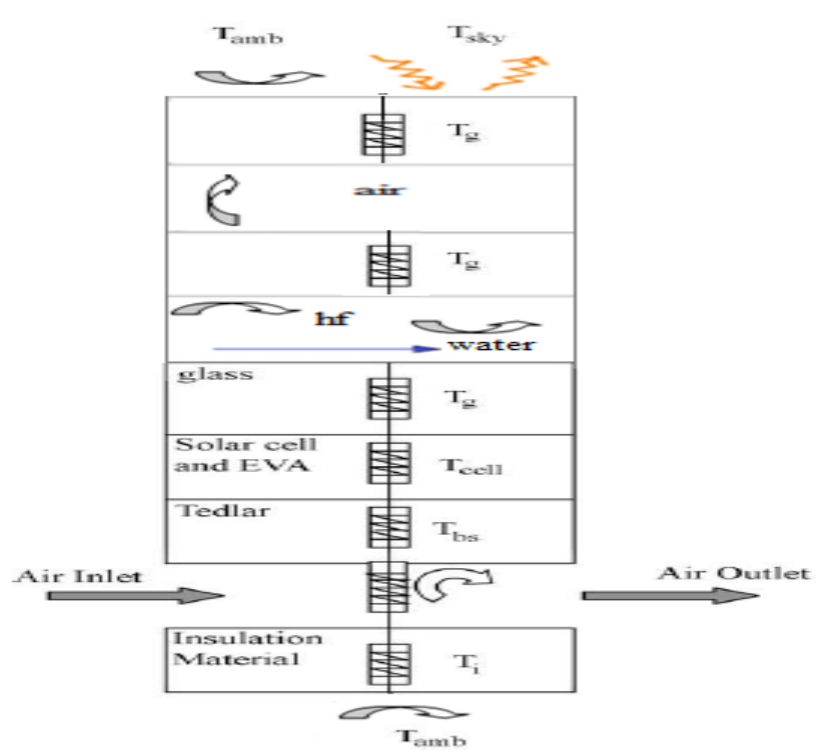

Figure. 4. Thermal resistance circuit diagram for dual PV/T collector (Model III).

The network determines the losses of the collector as convection and radiation. The top is represents the ambient with a temperature $T_{a}$. The second temperature is the cover temperature; there is radiative loss due to the temperature difference between the cover and ambient and convection due to wind. L osses from glass internal to cover external is through expressed as the sum of the convective losses due to the radiation and natural convection. A radiative loss exists from the cell to the cover. The conductive resistance term $\mathrm{L}_{\mathrm{si}} / \mathrm{K}_{\mathrm{si}}$ has been added to conductive heat transfer coefficient from solar cell to flowing air through tedlar. The convective heat transfer coefficient inside the air duct $\left(\mathrm{h}_{\mathrm{f}, \text { air }}\right)$ and inside the water duct $\left(\mathrm{h}_{\mathrm{f}, \text { water }}\right)$ are calculated according to flow regime and its Nusselt number. The back plate of the collector has a temperature $T_{b p}$, this causes convection and conduction that depends on the thickness and quality of the isolation lossed to the ambient $\mathrm{T}_{\mathrm{a}}$. 
In this research the overall heat transfer coefficient is variable. It includes all of conduction, convection and radiation losses from the dual $\mathrm{PV} / \mathrm{T}$ collector to the atmosphere.

\section{1 ) Thermal balance:}

The PVTh is a complex system that involves coupling of heat transfer between the various elements constituting it. Balance equations show the parameters that describe the geometry of the system, the nature of the flow of the water and the ambient air, losses by convection and radiation. The accuracy of the model depends strongly of these parameters.

The thermal energy balance equations for the different nodes of this collector are as follows:

$$
\begin{aligned}
& \alpha_{g} G=U_{1}\left(T_{g e}-T_{a}\right)+U_{2}\left(T_{g e}-T_{g i}\right) \\
& \tau_{g} \alpha_{g} G=U_{2}\left(T_{g i}-T_{g e}\right)+U_{a}\left(T_{g i}-T_{\text {celi }}\right)+Q_{\text {water } 1} \\
& (\tau \alpha)_{\text {eff }} G=U_{a}\left(T_{\text {cell }}-T_{\text {gi }}\right)+U_{T}\left(T_{\text {cell }}-T_{\text {abs }}\right)+Q_{\text {water }_{2} 2}(23 \\
& U_{T}\left(T_{\text {cell }}-T_{\text {abs }}\right)=h_{f, \text { air }}\left(T_{\text {abs }}-T_{f, \text { air }}\right) \\
& Q_{u-a i r}=Q_{a i r 11}+Q_{a i r_{2} 2}
\end{aligned}
$$

Solving this system of equations we can reach value of different temperature: $\mathrm{T}_{\text {ge }}, \mathrm{T}_{\mathrm{gi}}, \mathrm{T}_{\text {fout,water, }}, \mathrm{T}_{\text {cell }}, \mathrm{T}_{\mathrm{abs}}, \mathrm{T}_{\text {fout,air }}$, this resolution allows us to characterize the prototype power.

The radiative heat transfer coefficient term $\left(\mathrm{h}_{\text {rad,ve-sky }}\right)$ has been added to overall heat transfer coefficient from glass external to ambient $\left(\mathrm{U}_{1}\right)$. Further, the corresponding coefficient of convective loss caused by the wind can be calculated from equation $\left(\mathrm{h}_{\mathrm{c}, \text { wind }}\right)$.

$$
\begin{aligned}
& U_{1}=\left(\frac{1}{h_{\text {rad } g e-s k y}+h_{e_{d} \text { wind }}}+\frac{L_{g}}{\lambda_{g}}\right)^{-1} \\
& h_{\text {cwind }}=2.8+3 V_{w} \\
& h_{\text {rad } 1 \mathrm{ke}-\alpha}=\varepsilon_{\mathrm{v}} \sigma\left(T_{g e}^{2}+T_{\text {sky }}^{2}\right)\left(T_{g e}+T_{\text {sky }}\right)
\end{aligned}
$$

Where $V_{w}$ is wind speed on the top surface of $\mathrm{PV} / \mathrm{T}$ collector. The effective temperature of the sky $\left(\mathrm{T}_{\text {sky }}\right)$ is calculated from the following empirical relation [21]:

$$
T_{\text {sky }}=T_{a}-6
$$

The radiative heat transfer coefficient term $\left(\mathrm{h}_{\text {rad,ge-gi }}\right)$ has been added to convective heat transfer coefficient between glass external and glass internal $\left(\mathrm{U}_{2}\right)$.

$$
\begin{aligned}
& U_{2}=\left(\frac{1}{h_{\text {rad } g e-g i}+h_{e_{g} g-g i}}+\frac{L_{g}}{\lambda_{g}}\right)^{-1} \\
& h_{\text {rad } g e-g i}=\varepsilon_{v} \sigma\left(T_{g e}^{2}+T_{g i}^{2}\right)\left(T_{g e}+T_{g i}\right)
\end{aligned}
$$

Natural convection heat transfer coefficient between glass external and glass internal is given by the expression

$$
h_{\text {cige-gi }}=\frac{N_{u} \lambda_{\text {air }}}{w_{\text {air }}}
$$

The Nusselt number $\mathrm{Nu}$ calculated by using the following correlation [21].

$$
\begin{array}{ll}
G_{y}<1700+47.8 \phi \quad N_{u}=1.013 \\
G_{Y}>80000 & N_{u}=2.5+0.0133(90-\phi) \\
\text { Otherwise } & N_{u}=\left[0.06+3.10^{-4}(90-\phi)\right] G_{Y}^{0.3 a}
\end{array}
$$

$\mathrm{G}_{\mathrm{r}}$ is the Grashof number defined by

$G_{y}=\frac{g \beta \Delta T b^{d}}{v^{2}}$

$\beta:$ is being the thermal dilatation, for the air

$\mathrm{w}_{\text {air: }}$ duct depth of air .

$\Delta \mathrm{T}:$ Temperature difference between the two plans.

The radiative heat transfer coefficient term $\left(\mathrm{h}_{\mathrm{rad}, \text { gi-cell }}\right)$ is given by:

$$
U_{a}=\left(\frac{1}{h_{\text {rad gi-ceil }}}\right)^{-1}
$$

The conductive resistance term $\mathrm{L}_{\mathrm{si}} / \mathrm{K}_{\mathrm{si}}$ has been added to conductive heat transfer coefficient from solar cell to flowing air through tedlar $\left(\mathrm{U}_{\mathrm{T}}\right)$.

$$
U_{T}=\left(\frac{L_{g i}}{\lambda_{g i}}+\frac{L_{T}}{\lambda_{T}}\right)^{-1}
$$

The convective heat transfer coefficient inside the air duct $\left(\mathrm{h}_{\mathrm{f}, \text { air }}\right)$ has been assumed as constant factor.

For air:

The convective heat flux exchanged between the plate absorber at $\mathrm{T}_{\mathrm{abs}}$ and airflow at $\mathrm{T}_{\mathrm{f} \text {,air }}$ is defined as

$Q_{\text {air } 1}=\int_{0}^{L} h_{f, a i r}\left(T_{\text {abs }}-T_{f_{\text {air }}}\right) w_{\text {air }} d x$

The convective heat flux exchanged between the bottom of the collector at $\mathrm{Ta}$ and airflow at $\mathrm{T}_{\mathrm{f}, \text { air }}$ has been calculated by:

$Q_{\text {air } 2}=\int_{0}^{L} U_{b}\left(T_{a}-T_{f_{a} \text { air }}\right) w_{\text {air }} d x$

The bottom loss coefficient is calculated by:

$U_{b}=\left(\frac{L_{i}}{\lambda_{i}}+\frac{1}{h_{\text {conv }_{i} b}}\right)^{-1}$

The useful collected heat of the air flow is given by [18]:

$Q_{u-a i r}=Q_{a i r_{i} 1}+Q_{a i r_{2}}$

For water:

Heat flux transferred by convection to the working water from the internal glass is defined as

$Q_{\text {water } 1}=\int_{0}^{L} h_{f_{\text {w water }}}\left(T_{\text {gi }}-T_{f_{\text {water }}}\right) w_{\text {watey }} d x$

The heat flux transferred by convection to the working water from the photovoltaic module.

$Q_{\text {water } 2}=\int_{0}^{L} h_{f_{\text {water }}}\left(T_{\text {cell }}-T_{f_{\text {water }}}\right) w_{\text {watey }} d x$ 
The outlet temperature and the useful collected heat of the water flow are calculated by equation (17) and equation (18) respectively.

In this way, a thermal efficiency is defined:

$$
\begin{aligned}
& \eta_{\text {th-air }}=\frac{\dot{m} C_{\text {air }}\left(T_{\text {fout }}-T_{\text {fin }}\right)}{w L G} \\
& \eta_{\text {th-water }}=\frac{\dot{m} C_{\text {water }}\left(T_{\text {fout }}-T_{\text {fin }}\right)}{w L G}
\end{aligned}
$$

The electrical efficiency of solar cell depends on solar cell temperature. First, is assumed equal to the electrical efficiency at the reference conditions $\left(\eta_{\mathrm{el}}=\eta_{\mathrm{el}, \mathrm{ref}}=0.12\right)$. Then, the value of $T_{\text {ge }}, T_{\text {gi }}, T_{\text {cell }}, T_{\text {fout,water }}$ and $T_{\text {f,out,air }}$ are calculated from Eqs. (21) - (25), respectively. After finding the value of those temperatures the electrical efficiency must be updated. The electrical efficiency is updated by solving the electrical model with $T_{\text {cell }}, T_{a}$ and $G$ as input data to the model. Iteration is continued until the difference of electrical efficiency in two successive iteration to be less than predefined tolerance.

\section{PARAMETRIC STUDIES}

The values of climatic, operating and design parameters in the parametric studies of $\mathrm{PV} / \mathrm{T}$ dual collector and the parameters needed to plot the following figures have been summarized given in Table 1.

The typical results of computer simulation program under the sample conditions of Table $1, T_{\text {fin }}=T_{a}=300 \mathrm{~K}, V_{\text {in }}=1 \mathrm{~m} / \mathrm{s}, \mathrm{G}$ $=1000 \mathrm{~W} / \mathrm{m}^{2}$ has been given in Table 2 .

\begin{tabular}{|c|c|}
\hline Solar $\mathrm{PV} / \mathrm{T}$ collector parameters & Value \\
\hline $\begin{array}{l}\text { The solar radiation intensity at the reference } \\
\text { conditions, } G_{\text {ref }}\end{array}$ & $1000 \mathrm{~W} / \mathrm{m}^{2}$ \\
\hline $\begin{array}{l}\text { The ambient temperature at reference conditions, } \\
\mathrm{T}_{\mathrm{amb}, \mathrm{ref}}\end{array}$ & $298 \mathrm{~K}$ \\
\hline $\begin{array}{l}\text { The solar cell temperature at reference conditions, } \\
\mathrm{T}_{\text {cell,ref }}\end{array}$ & $298 \mathrm{~K}$ \\
\hline $\begin{array}{l}\text { The electrical efficiency at the reference conditions, } \\
\eta_{\text {el,ref }}\end{array}$ & 0.12 \\
\hline The thickness of glass cover, $\mathrm{L}_{\mathrm{g}}$ & $0.003 \mathrm{~m}$ \\
\hline The conductivity of glass cover, $\lambda_{\mathrm{g}}$ & $0.04 \mathrm{~W} / \mathrm{m} \mathrm{K}$ \\
\hline The transmittivity of glass cover, $\tau_{\mathrm{g}}$ & 0.9 \\
\hline The absorptivity of glass, $\alpha_{\mathrm{g}}$ & 0.066 \\
\hline The emissivity of glass, $\varepsilon_{\mathrm{v}}$ & 0.88 \\
\hline The emissivity of cell, module, $\varepsilon_{\text {cell }}$ & 0.95 \\
\hline The transmittivity of cell, module, $\tau_{\text {cell }}$ & 0.87 \\
\hline The absorptivity of cell, module, $\alpha_{c}$ & 0.9 \\
\hline The thickness of silicon solar cell, $\mathrm{L}_{\mathrm{si}}$ & $300 \times 10^{-6} \mathrm{~m}$ \\
\hline The conductivity of silicon solar cell, $\lambda_{\mathrm{si}}$ & $0.039 \mathrm{~W} / \mathrm{m} \mathrm{K}$ \\
\hline The absorptivity of tedlar, $\alpha_{\mathrm{T}}$ & 0.5 \\
\hline The thickness of tedlar, $\mathrm{L}_{\mathrm{T}}$ & $0.0005 \mathrm{~m}$ \\
\hline The conductivity of tedlar, $\lambda_{\mathrm{T}}$ & $0.033 \mathrm{~W} / \mathrm{m} \mathrm{K}$ \\
\hline The thickness of back insulation, $\mathrm{L}_{\mathrm{i}}$ & $0.05 \mathrm{~m}$ \\
\hline The conductivity of back insulation, $\lambda_{\mathrm{i}}$ & $0.035 \mathrm{~W} / \mathrm{m} \mathrm{K}$ \\
\hline The length of duct, $\mathrm{L}$ & $1.22 \mathrm{~m}$ \\
\hline The width of PV/T collector, w & $0.855 \mathrm{~m}$ \\
\hline The packing factor of solar cell, $\beta_{\mathrm{c}}$ & 0.83 \\
\hline $\begin{array}{l}\text { The wind speed, } \mathrm{V}_{\mathrm{w}} \\
\text { water flow, v́ }\end{array}$ & $\begin{array}{l}1 \mathrm{~m} / \mathrm{s} \\
76 \mathrm{~m}^{3} / \mathrm{h}\end{array}$ \\
\hline Collecteur angle, $\phi$ & $36^{\circ}$ \\
\hline $\begin{array}{l}\text { The duct depth, air, } \mathrm{w}_{\text {air }} \\
\text { The duct depth, water, } \mathrm{w}_{\text {eau }}\end{array}$ & $\begin{array}{l}0.01 \mathrm{~m} \\
0.01 \mathrm{~m}\end{array}$ \\
\hline
\end{tabular}

Table1. Ambient conditions and design used in simulations

\section{RESULTAT AND DISCUSSION}

Solving the system of equations governing the heat transfer in the prototype allows estimate the thermal and electrical performance of the prototype.

Eqs (21)-(25) of the thermal energy balance have been computed by the Matlab program for the external temperature of cover $\left(\mathrm{T}_{\mathrm{ge}}\right)$, internal temperature of glad $\left(\mathrm{T}_{\mathrm{gi}}\right)$, outlet water temperature $\left(T_{f, \text { water }}\right)$, back surface of module $\left(T_{a b s}\right)$, solar cell $\left(\mathrm{T}_{\text {cell }}\right)$ temperature and outlet air temperature $\left(\mathrm{T}_{\mathrm{f}, \mathrm{air}}\right)$ in the $\mathrm{PV} / \mathrm{T}$ dual collector.

Increasing the solar radiation intensity, the solar cell and outlet temperature of the various PVT-panels increases initially and then decreases after attaining solar radiation intensity of about a maximum point. The Hourly variation of solar cell temperature, outlet air temperature and outlet water temperature with time are displayed in Fig. 5, and Fig. 6. The solar cell temperature and outlet air temperature in module $\mathrm{PV} / \mathrm{T}$ air with tedlar (Model I) is higher than the value for (Model II) without tedlar.

Fig. 7 shows thermal efficiency variation at various PVTpanels, these results are referred to thermal efficiency of water $\eta_{\text {th } / \mathrm{w}}$ in the mode of water heat exchanger, and air $\eta_{\text {th } / \mathrm{a}}$ heat extraction for (model I) and (Model II), regarding the ration $\Delta \mathrm{T} / \mathrm{G}\left(\mathrm{KW}^{-1} \mathrm{~m}^{2}\right)$ is the reduced temperature, with $\Delta \mathrm{T}=\mathrm{T}_{\mathrm{i}}-\mathrm{T}_{\mathrm{a}}$ (K). The PV/T air collector without tedlar is obviously performing poorest at zero reduced temperature and PVT water collector represents a higher value.

From the presented results of Fig. 8 we can see that the mode with water heat exchanger, presented a higher value than the value for two other model. As the solar cell temperature in the case of PV/T with tedlar is higher than the value for (model II) consequently the electrical efficiency in model without tedlar is higher than for (model I), because in this case all the radiation is absorbed by the tedlar and then heat is carried away by the conduction. So that the temperature of the solar cell is higher, result in decrease in efficiency of module.

The outlet temperature is linearly proportional to the irradiation and ambient temperature, and it is displayed in Fig. 9 and Fig. 10. It seen that the outlet water temperature $\left(T_{f, w a t e r}\right)$ is significantly higher than the outlet air temperature. The outlet water temperature in Model III is higher than the value for model IV.

The temperatures of solar cell for the two configurations of dual $\mathrm{PV} / \mathrm{T}$ collector are linearly proportional to the solar radiation, as shown in Fig.11. It value is higher in the Model III. The higher temperature occurs at solar cell, this is attributed to the high absorption of solar irradiation in silicon cell. Temperature of tedlar is higher than top glass.

The Fig. 12, Fig. 13 and Fig. 14 show the effect of radiation intensity on the outlet temperature at various flow rates, in two configuration of dual PVT model. The outlet temperature is proportional to the radiation intensity at a specific mass flow rate. It can see that at same solar radiation the collector which operates at low flow rate will experience high outlet temperature. It can see also that Model III presents the high outlet temperature at low rate than the value for Model IV. 


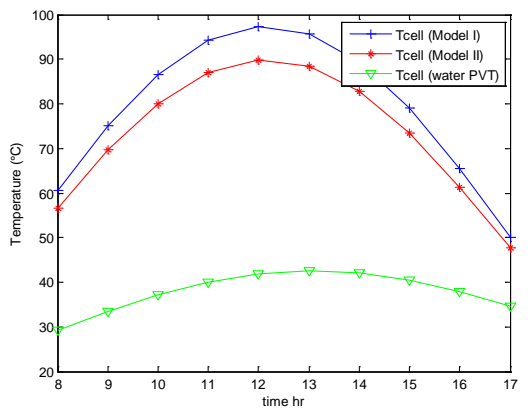

Fig. 5. Hourly variation of solar cell temperature with time

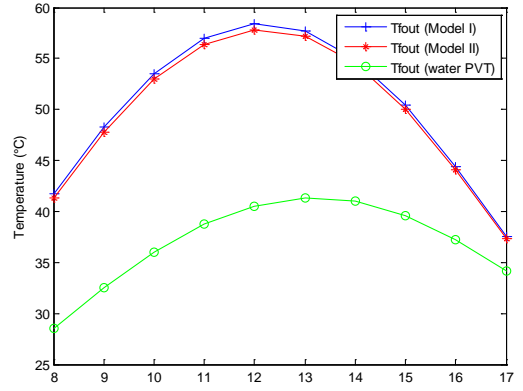

Fig. 6. Hourly variation of outlet temperature with time

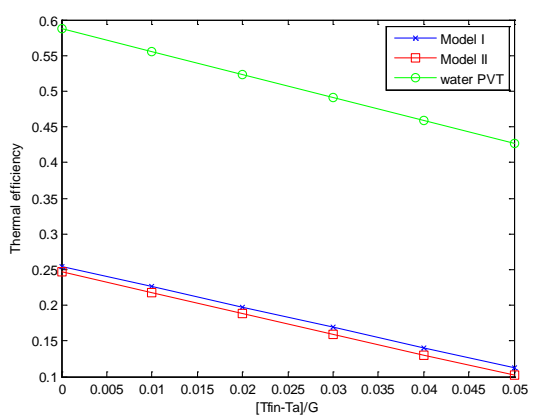

Fig. 7. Thermal efficiency for the case of the various PVT-panels.

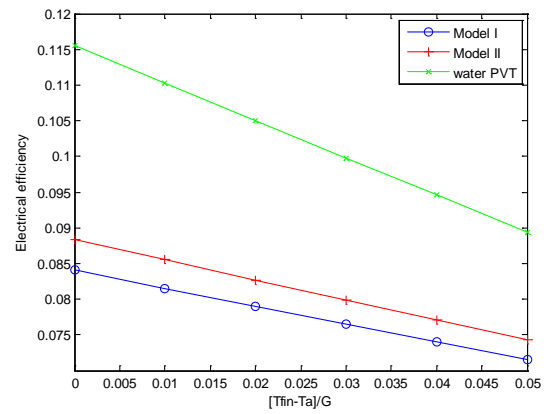

Fig. 8. Electrical efficiency for the case of the various PVT-panels.

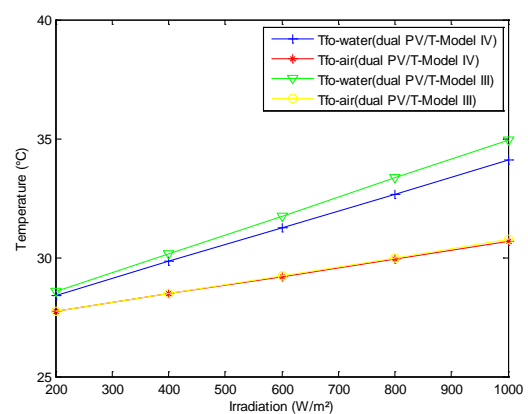

Fig. 9. Variation of outlet temperature of dual PV/T systems with solar radiation

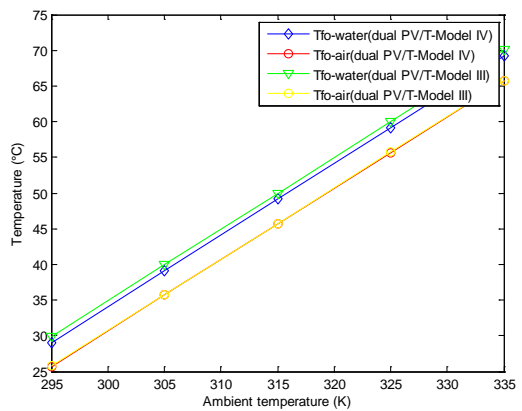

Fig. 10. Variation of outlet temperature of dual PV/T system with ambient temperature

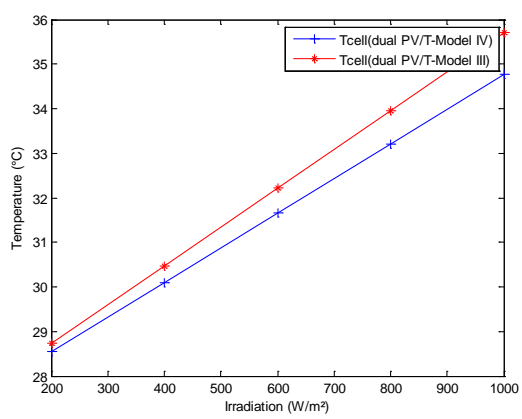

Fig. 11. Variation of solar cell temperature of dual PV/T system with solar radiation

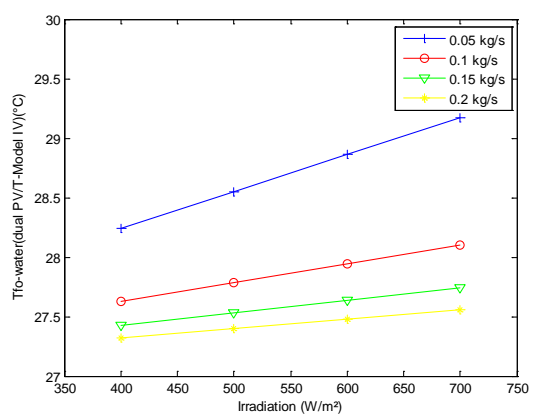

Fig. 12. The effect of solar radiation on the water outlet temperature of dual PV/T (Model IV) at various mass flow rate of water.

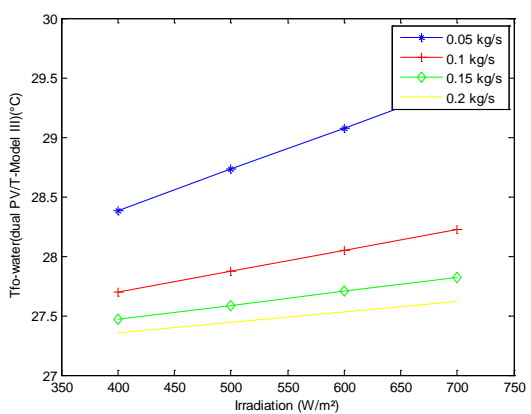

Fig. 13. The effect of solar radiation on the water outlet temperature of dual PV/T (Model III) at various mass flow rate of water. 


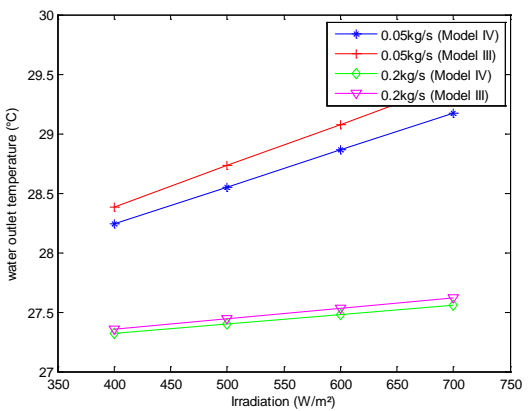

Fig. 14. The effect of solar radiation on the water outlet temperature of two dual PV/T collector (Model III-Model IV) at various mass flow rate of water

\section{CONCLUSION}

We have presented the different configurations of hybrid collectors which are defined as unglazed PV/T air heaters, with and without tedlar, PVT hybrid water collector. Further, the two configurations with dual extraction operations (water and air as heat removal fluid) are presented as dual $\mathrm{PV} / \mathrm{T}$ model with tedlar, dual hybrid $\mathrm{PV} / \mathrm{T}$ without tedlar. The simulation model can predict the system performance such $\mathrm{T}_{\mathrm{f} \text {,water }}, \mathrm{T}_{\mathrm{f} \text {,air }}, \mathrm{T}_{\text {cell }}$ for different solar radiation, different ambient temperatures and different mass flow rates.

The results of different configurations have been compared; these clearly show the direct impact of various parameters, in particular the solar radiation, ambient temperature, mass flow rate on the variation of outlet and solar cell of the collector.

Both air and water can be used as the coolant in a P V module to low down the solar cell operating temperature and hence to improve the electricity conversion performance. Comparatively, the water-based products are more effective than those air-based because of the favourable thermal properties of water.

The gotten results permit to say that the photovoltaic panel is a cal orific energy generator that can be exploited to heat water or for the preheating of the space or again to associate it with a heat pump for the air-conditioning.

\section{REFERENCES}

[1] Nobuyuki H. Renewable energy: RD \& D priorities: insights from IEA technology programmes; 2006.

[2] H.Benis, M.Marir- Benabbas,' Hot Spot Phenomena in Solar Modules', International Review of Physics (IREPHY), ISSN 1971-680X, Vol.6 N.1 February 2012

[3] Kern, E.C. and Russell, MC. Combined photovoltaic and thermal hybrid collector system. Proceedings of $13^{\text {th }}$ IEEE Photovoltaic Specialist. pp. 1153-1157. 1978

[4] Hendrie S.D. and Raghuaraman P. Comparison of theory and experimental for photovoltaic thermal performance Proceedings of $14^{\text {th }}$ IEEE Photovoltaic Specialist conference, San Diego. 1980.

[5] Arvind Tiwari, M.S. Sodha, Parametric study of various configurations of hybrid PV/thermal air collector: Experimental validation of theoretical model, Solar Energy Materials \& Solar Cells 91 (2007) 17-28.

[6] Tiwari, M.S. Sodha, A. Chandra, J.C. Joshi, Sol. Energy Master. Sol. Cells 90 (2) (2006) 175

[7] Sujata Nayak and Arvind Tiwari , Performance Evaluation of an Integrated Hybrid Photovoltaic Thermal (PV/T) Greenhouse System, International Journal of Agricultural Research 2(3):211-226,2007.

[8] Anand S.Joshi, Arvind Tiwari, Energy and exergy efficiencies of a hybrid photovoltaic-thermal (PV/T) air collector, Renewable Energy 32 (2007) 2223-2241.
[9] Swapnil Dubey and G.N. Tiwari. Life Cycle Cost Analysis and Carbon Credit Earned by Hybrid PV/T Solar Water Heater for Delhi Climatic Conditions. OpenEnvironmental Sciences, 2008,2,15-25.

[10] Dubey S, Sandhu GS, Tiwari GN. Analytical expression for electrical efficiency of PV/T hybrid air collector. Appl Energy 2009; 86(5):697705.

[11] Swapnil Dubey, S.C. Solanki, Arvind Tiwari. Energy and exergy analysis of PV/T air collectors connected in series. Energy and Buildings 41(2009)863-870.

[12] TT Chow. A review on photovoltaic/thermal hybrid solar technology. Appl Energy 2010; 87: 365-79.

[13] F. Sarhaddi, S. Farahat, H. Ajam, A. Behzadmehr, M. Mahdavi Adeli, An improved thermal and electrical model for a solar photovoltaic thermal (PV/T) air collector, Applied Energy 87 (2010) 2328-2339.

[14] Adnan Ibrahim , Mohd Yusof Othman, Mohd Hafidz Ruslan, Sohif Mat, Kamaruzzaman Sopian, Recent advances in flat plate photovoltaic/thermal (PV/T) solar collectors, Renewable and Sustainable Energy Reviews 15 (2011) 352-365.

[15] H.A. Zondag, Flat-plate PV-Thermal collectors and systems A review, Renewable and Sustainable Energy Reviews 12 (4) (2008) 891-959.

[16] H.G. Teo , P.S. Lee, M.N.A. Hawlader, An active cooling system for photovoltaic modules, Applied Energy 90 (2012) 309-315.

[17] Florschuetz LW, on heat rejection from terrestrial solar cell arrays with sunlight concentration, IEEE Photovolt Spec Conf Rec Mater 1975:31826.

[18] Yves JANNOT, THERMIQUE SOLAIRE, 2011.

[19]Rapport de Stage, Pré-étude d'un système couplé Photovoltaïque/Thermique, Universite Joseph Fourier,2010.

[20] H.A. Zondaga , D.W. de Vriesa, W.G.J. van Heldenb, R.J.C. van Zolingenc, a A.A. van Steenhoven, The yield of different combined PVthermal collector Designs, Solar Energy 74 (2003) 253-269.

[21] Jacques BERNARDS, " Energie solaire Calculs et optimisation», Edition Ellipses, Août 2004 France.

\section{Creative Commons Attribution License 4.0} (Attribution 4.0 International, CC BY 4.0)

This article is published under the terms of the Creative Commons Attribution License 4.0 https://creativecommons.org/licenses/by/4.0/deed.en_US 